\section{Cinco reflexiones sobre arquitectura religiosa contemporánea}

Five reflections on contemporary religious architecture

FERNANDO AGRASAR QUIROGA

https://doi.org/10.17979/aarc.2007.1.0.5032

Estoy aquí en representación de Celestino García Braña, Decano del Colegio Oficial de Arquitectos de Galicia, cuya ausencia me ruega que excuse. En primer lugar quisiera felicitar, en nombre del Decano y en el mío propio, a todos los organizadores y participantes. También quiero decirles que este congreso culmina un proceso de conversaciones y ediciones, y al tiempo, es una primera etapa de futuras iniciativas. Una de las piezas fundamentales del proceso al que me refiero es la edición de la monografía sobre arquitectura contemporánea en España del que es autor Esteban Fernández Cobián. Este libro fue publicado por el Colegio Oficial de Arquitectos de Galicia recientemente. Su Comisión de Cultura y su Decano están muy satisfechos del resultado, entre otras razones porque, como se ha señalado hace un instante, la historiografía moderna tiene una deuda con la arquitectura religiosa que debe subsanarse y a ello queremos contribuir.

Mi trabajo de investigación no está vinculado a la arquitectura religiosa contemporánea, pero dos trabajos recientes, dos tareas en las que estoy involucrado, me han aproximado de una manera intensa a este fenómeno arquitectónico. En primer lugar desde mi participación en el proyecto SUDOE, que es una catalogación de arquitectura española del siglo XX que recoge piezas de interés delimitadas por las fronteras temporales del siglo XX, en donde se han recogido numerosísimas entradas de arquitectura religiosa. $\mathrm{Y}$ es realmente interesante constatar el peso, el valor y la calidad de estas piezas en el conjunto de lo que hemos propuesto como arquitecturas de interés y de valor en todo el siglo XX español. En segundo lugar, desde la comisión técnica de la Fundación DoCoMoMo Ibérico, llevando a cabo la tarea de catalogar y registrar piezas arquitectónicas de adscripción moderna, entre las que se están recogiendo importantes, y numerosos, edificios religiosos.

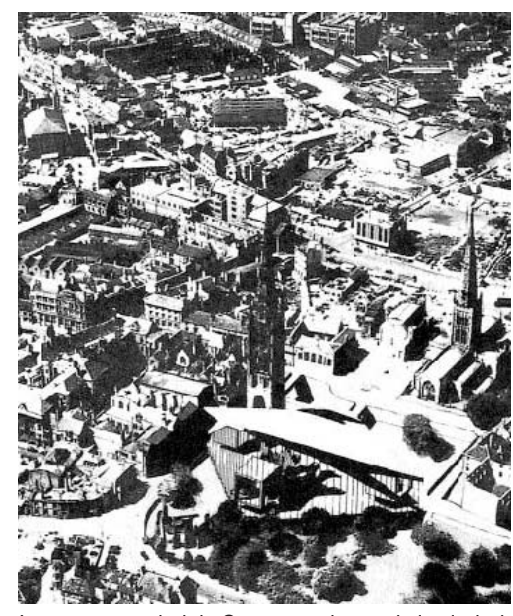

La nueva catedral de Conventry dentro de la ciudad.

I am here on behalf of Celestino Garcia Braña, Dean of the Official Association of Architects of Galicia, and I would like to apologise for his non-attendance. First of all, I would like to congratulate all the organisers and participants on behalf of the Dean and on my own. I would also like to say that this conference culminates a process of conversations and editions and it is, at the same time, the first stage of the coming initiatives. One of the basic pieces of the process that I am referring to is the monographic on contemporary architecture in Spain by Esteban Fernández Cobián. This book was recently published by the Official Association of Architects of Galicia. Both the Culture Commission and the Dean are very pleased with this result, because, among other reasons, as it was mentioned, modern historiography owes something to religious architecture and this must be repaid. We would like to contribute to that.

My research work is not linked to contemporary religious architecture. However, two recent works, a couple of tasks that I am involved with, have brought me very close to this architectural phenomenon. First of all, my participation in the SUDOE project, which is a catalogue of Spanish architecture of the 20th century compiling some interesting pieces framed within the time limit of the 20th century. Numerous religious architecture entries were collected there. It is really interesting to note the weight, value and quality of those pieces within the set proposed as interesting 


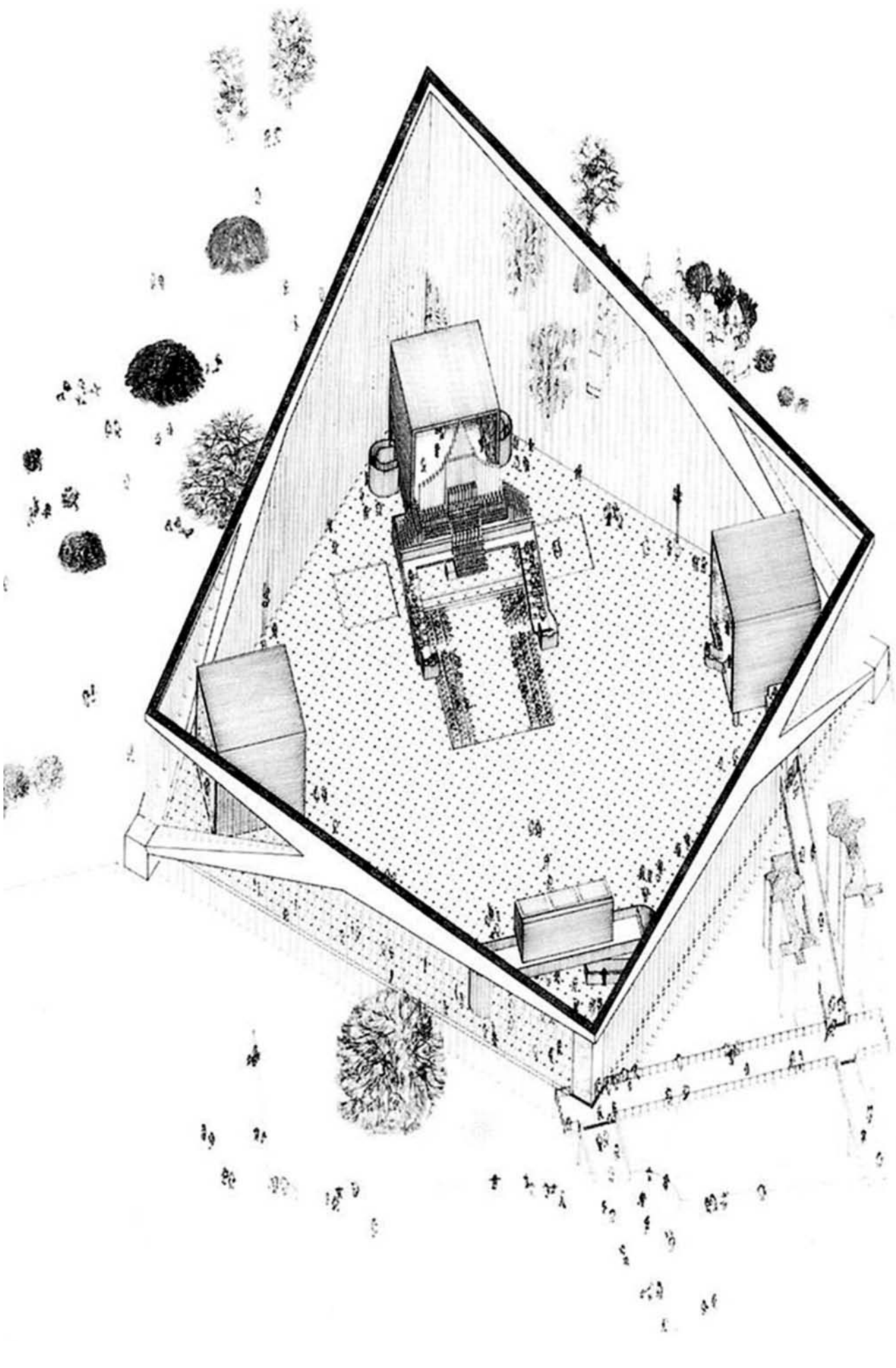




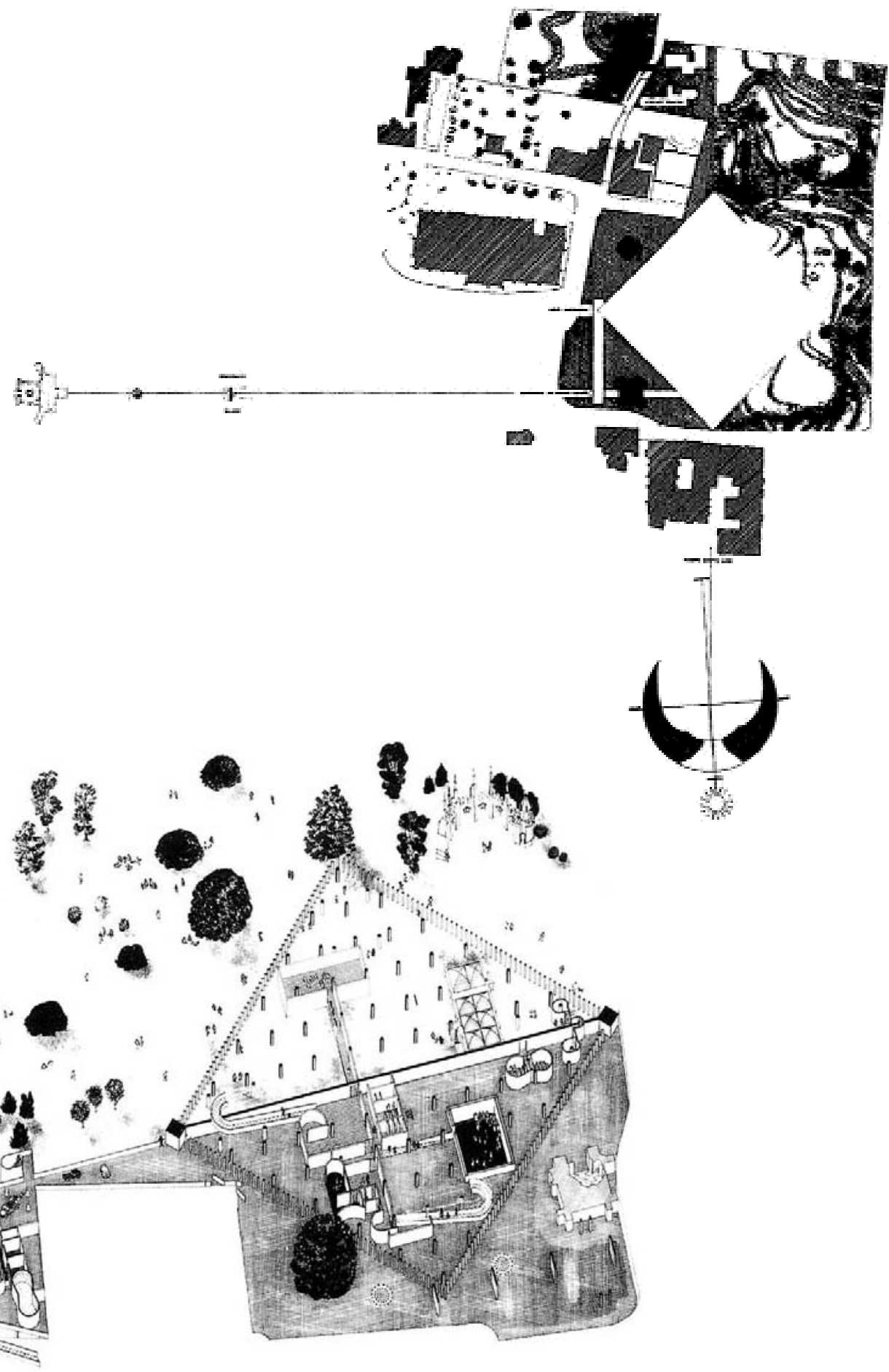

Catedral anglicana de Conventry. Planos del proyecto. 
and valuable architecture from the Spanish 20th century. Secondly, from the technical commission of the DoCoMoMo Ibérico Foundation, I have carried out the task of cataloguing and registering modern architectural pieces, among which a great number of important religious buildings is found.

I would briefly like to point out a few ideas -5, actually-, about contemporary religious architecture. If you allow me, I will go ahead.

The few pictures I have brought so as to support my brief presentation refer to an unbuilt architecture: the Coventry cathedral project, by Alison \& Peter Smithson, between 1950 and 1951. The work and, in particular, the thoughts of both architects are hugely important in the development of architecture during the second half of the 20th century. Modern architectural historiography also owes something to them, by the way, apart from the debt to religious architecture. These issues are directly and intensely portrayed in the pictures of the unbuilt Coventry cathedral -one of the characteristics of the work of both British architects-. These questions are also key to the relationship between modern and contemporary architecture and the religious one.

First of all: the issue of the typology inertia. That is, the difficulty posed by planning a sacred building upon which an enormous historical weight will undoubtedly fall. Temples have always been the essential architectural topic. Together with palaces, they have been the two main themes of architecture, practically the only two until the Industrial Revolution. During the eclectic architecture period, in the late 20th century, town planners would scatter churches around the tissue of the enlargements following the same order criterion used to distribute markets and hospitals. A whole new range of town typologies was born at that point in time, and the situation maintained since civilisation started was broken. That breaking marked the religious architecture of that time and that which would be projected throughout the whole 20th century, with the psychological burden of a very brilliant history, a heavy legacy which has always gravitated above the temple composition.

Secondly, the tension between function and form is the angular stone of modernity. That is, according to Sullivan, shape follows function and from there to his disciple Frank Lloyd Wright, the whole modern composition was developed. Therefore, the definition of function in temples has important architectural consequences, so

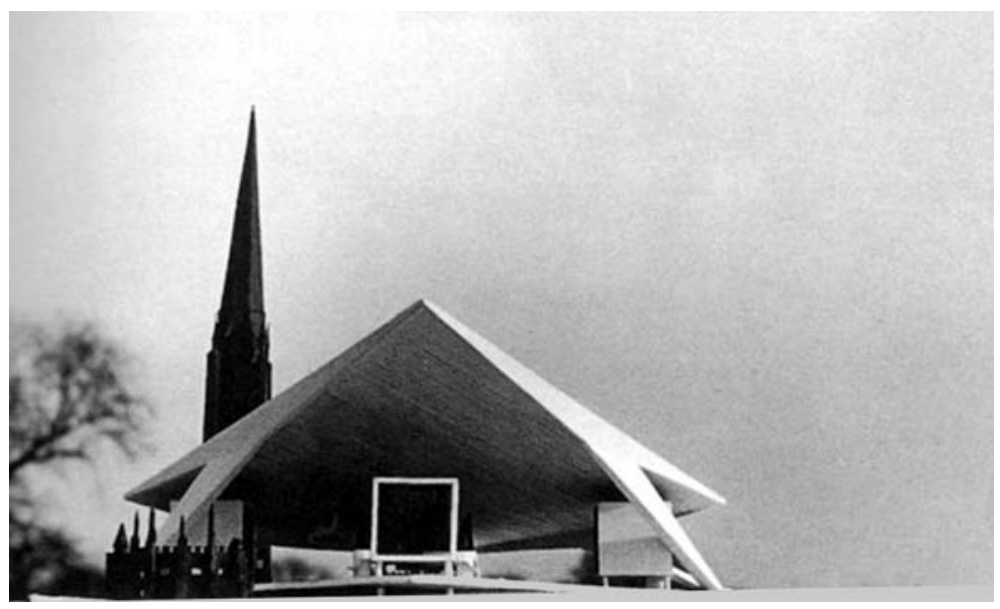

Catedral anglicana de Conventry. Maqueta de la propuesta.

De forma breve quisiera apuntar unas ideas - cinco, en concretosobre arquitectura religiosa contemporánea. Si me lo permiten, voy a proceder a ello.

Las pocas imágenes que he traído para apoyar esta mínima intervención son de una arquitectura no construida: el proyecto de la catedral anglicana de Coventry, del que son autores Alison y Peter Smithson (1950/51). Unos arquitectos, cuya obra y, sobre todo, cuyo pensamiento son capitales en el desarrollo de la arquitectura de la segunda mitad del siglo XX, y con los que las historiografía de la arquitectura moderna, por cierto, también tiene un deuda, además de con la arquitectura religiosa. En estas imágenes de la no construida Catedral de Coventry se recogen de manera muy directa y muy intensa - como es característico en la obra de estos dos arquitectos británicos - estas cuestiones que, entiendo, son claves en la relación de la arquitectura moderna y contemporánea con la arquitectura religiosa.

En primer lugar: la cuestión de la inercia tipológica. Es decir, la dificultad que entraña plantear una construcción sacra sobre la que inevitablemente gravitará un peso histórico formidable. El templo ha sido el tema arquitectónico por excelencia. Junto con el palacio, han sido los dos grandes temas de la arquitectura, prácticamente los dos únicos hasta la Revolución Industrial. En el periodo de la arquitectura ecléctica, a finales del siglo XIX, los urbanistas distribuían las iglesias en el tejido de los ensanches con el mismo criterio de orden con el que situaban mercados u hospitales. En ese momento apareció un abanico amplísimo de nuevas tipologías edilicias, quebrándose una situación mantenida desde los orígenes de la civilización. Aquella ruptura marcó la arquitectura religiosa de aquel momento y la que se proyectaría a lo largo de todo el siglo XX, con el lastre psicológico de una historia brillantísima, de pesado legado, que ha gravitado constantemente sobre la composición del templo. 
En segundo lugar, la tensión entre función y forma, que es la piedra angular de la modernidad. Es decir, desde «la forma sigue a la función» de Sullivan, hasta «forma y función son una sola cosa», de su discípulo Frank Lloyd Wright, se desarrolla toda la composición moderna. Por esto, la definición de función en el templo tiene importantes consecuencias arquitectónicas, de forma que no puede entenderse la historia moderna de la arquitectura religiosa sin las variaciones introducidas en el culto religioso y los diversos planteamientos del papel social de la Iglesia.

Por otro lado, y casi como idea fundamental, surge el problema de la caracterización espacial del templo. Porque el templo es siempre - ha sido, también en buena parte de la experiencia moderna - un espacio ensimismado, un espacio que mira exclusivamente hacia dentro, donde no hay referencias exteriores. El edificio de Siza en Marco de Canaveses quiebra este orden, esta convención, esta inercia de la arquitectura religiosa, y también, y de una manera casi brutal, también lo hace el proyecto de los Smithson, con un enorme paraboloide hiperbólico abierto en su fachada este a la destrucción de Coventry, a los restos de la ciudad bombardeada, todavía visibles en 1950.

Por esto, y por la necesidad de una nueva formulación del templo contemporáneo, son tan abundantes los ejemplos recientes en los que el edificio religioso se piensa, se concibe y se compone como un hito en el paisaje. Cada vez menos es un elemento más del tejido urbano, y cada vez más es un edificio, una pieza arquitectónica, una pieza artística que dialoga y construye paisaje.

$\mathrm{Y}$ en último lugar, el problema de la expresión artística contemporánea, que es una cuestión no resuelta y que arrastra enormes lastres en cuanto a la propia naturaleza. Este conflicto fue generado por la irrupción de las vanguardias en las primeras décadas de siglo, al situar la expresión contemporánea de lo espiritual fuera de la tradición religiosa $y$, con frecuencia, en el contexto de un agnosticismo militante. Desde la materialidad de la abstracción, desde el legado de la nueva visión de las vanguardias, esa comunicación de lo espiritual, ese peso simbólico y representativo de lo trascendente, exige una reflexión en profundidad desde la disciplina artística y, claro está, desde la creencia religiosa. that the modern history of religious architecture cannot be understood without the variations introduced to religious worship and the various approaches to the Church's social role.

On the other hand - and this is a key idea-, the issue of the spatial characterisation of temples arose. Temples have always been - also during a great part of modern experience - withdrawn spaces, spaces looking inwards and with no outer references. Siza's building in Marco de Canaveses breaks with this order, with this convention, with this inertia of religious architecture and also does the Smithsons' project, almost brutally so. This was a huge hyperbolic parable with an Eastern façade open to the destruction of Coventry, to the remains of the bombed city, still visible in 1950.

That is why there are so many recent examples in which religious buildings are thought, conceived and composed as a milestone in the landscape, also due to the need for a new formulation of contemporary temples. It is less often an element of urban landscape, and more often a building, an architectural piece, a work of art which holds a dialogue and builds the landscape.

Finally, the pending issue of contemporary artistic expression which drags a huge ballast with regard to its own nature. This conflict was caused by the arrival of the avant-gardes during the first decades of the century, when the contemporary expression of the spiritual was placed outside religious tradition and, often, within the context of a militant agnosticism. From the materiality of abstraction, from the legacy of the new vision of the avant-gardes, that communication of spirituality, that symbolic and representative weight of what is transcendent, requires a deep reflection by the artistic field and, obviously, from a religious belief. 


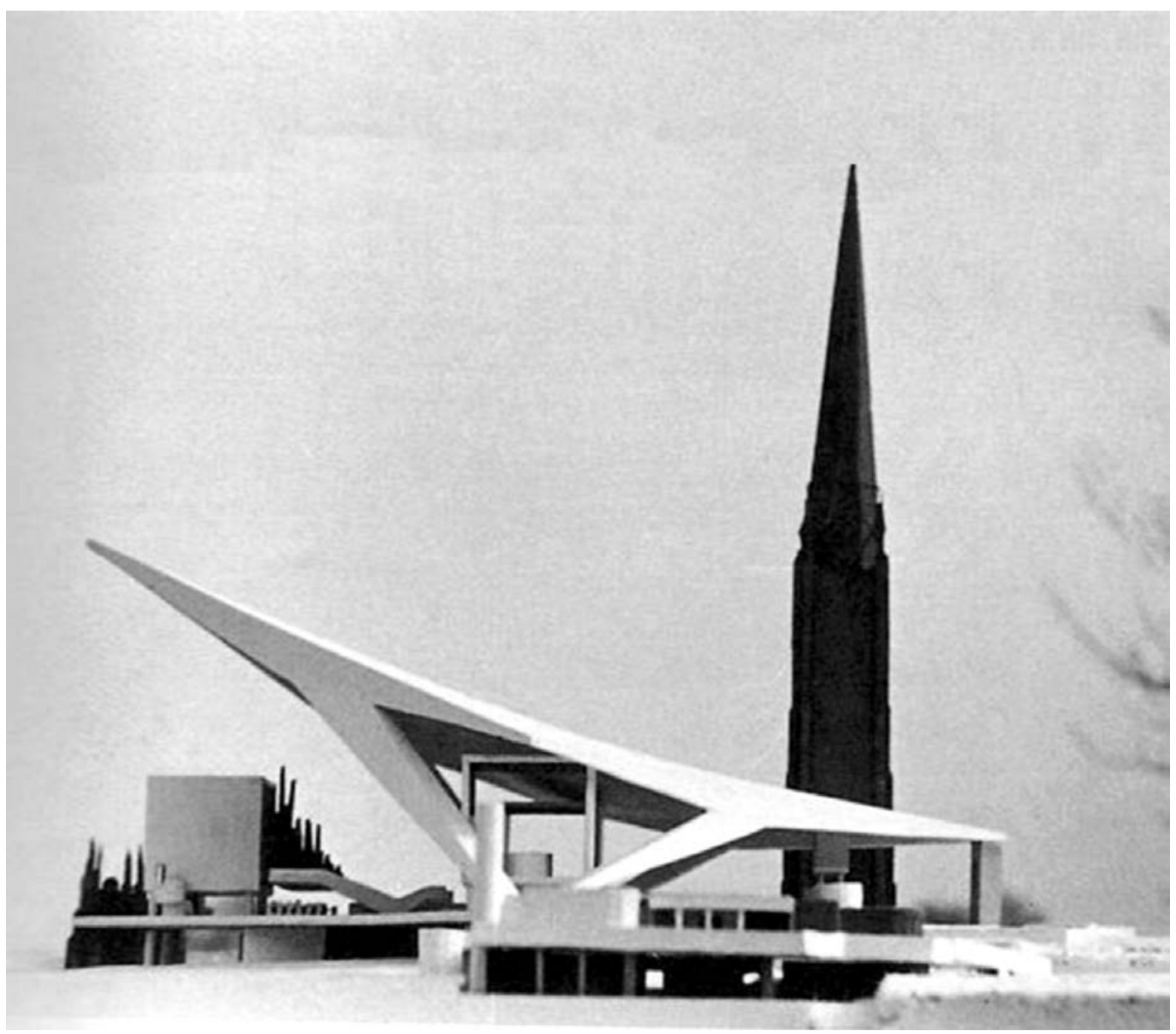

